\title{
Case Report of Haemophilus parainfluenzae Sepsis in a Newborn Infant Following Water Birth and a Review of Literature
}

\author{
Manu Kaushik, MBBS ${ }^{1}$ Brittany Bober, BSN ${ }^{1} \quad$ Leonard Eisenfeld, MD ${ }^{1} \quad$ Naveed Hussain, MBBS, MD, DCH ${ }^{1}$ \\ ${ }^{1}$ Division of Neonatology, Department of Pediatrics, Connecticut \\ Children's Medical Center and University of Connecticut School of \\ Address for correspondence Naveed Hussain, MBBS, MD, DCH, \\ Division of Neonatology, Department of Pediatrics, Connecticut \\ Medicine, Farmington, Connecticut \\ Children's Medical Center-NICU, 263 Farmington Avenue, Farmington, \\ CT 06030-2948 (e-mail: hussain@uchc.edu).
}

Am J Perinatol Rep 2015;5:e188-e192.
Abstract
Keywords
- water birth
- neonatal sepsis
- haemophilus parainfluenzae
- case report

Water birth has grown in popularity over the recent years. Although beneficial for mothers, there are concerns for the infants. There are previous reports of infection following water birth. The information regarding infection with Haemophilus parainfluenzae is limited. We report a case of a neonate with $H$. parainfluenzae bacteremia following water birth. The child was successfully treated with both antibiotic and supportive care. Previous reports of neonatal $H$. parainfluenzae infection are reviewed.
Water birth has become an increasingly popular alternative to hospital delivery as it is thought to provide maternal benefits, including less discomfort, decreased need for analgesics or anesthesia, and decreased perineal trauma. ${ }^{1,2}$ Immersion in water during the first stage of labor has some beneficial effects for the mother, but water immersion during the second stage of labor has not been adequately studied for safety and efficacy. ${ }^{3,4}$ Water birth has been deemed safe for infants in a few studies, but these have been mostly retrospective reports or studies with a small sample size. ${ }^{5}$ Bacterial colonization of infants does not seem to differ between normal births and water births. ${ }^{6}$ Despite putative physical and emotional benefits for mothers, underwater delivery has been linked to rare but serious adverse effects for newborns. These include respiratory distress and drowning from tubwater aspiration, pneumonia, sepsis, seizures, and perinatal asphyxia. ${ }^{7,8}$ There have been many small sample size reports but no randomized controlled trials on this subject. ${ }^{9}$ It is notable that there is no mention of this mode of birth in the medical, health, and newborn sections of the 2003 U.S. Standard Certificate of Live Birth. ${ }^{10}$

Case reports of water births have raised concerns that the "protective" reflex that prevents the newborn from aspirating is sometimes overridden especially in stressed or compromised infants at birth resulting in aspiration pneumonia. ${ }^{11,12}$ Moreover, sepsis may occur, most commonly because of Pseudomonas aeruginosa, ${ }^{13,14}$ Legionella pneumophila, ${ }^{15-18}$ and Group B streptococcus (GBS), ${ }^{19,20}$ which may be found in maternal genitourinary and gastrointestinal tract and can proliferate in an aqueous environment. Cases of transmission of gastrointestinal tract-related adenovirus have been reported. ${ }^{21}$ Infections because of these organisms could have serious and life-threatening sequelae.

$H$. parainfluenzae is an organism that is known to cause chorioamnionitis $^{22}$ and neonatal infection through maternal-infant transmission. ${ }^{23-27}$ It is present in the maternal genital tract and can thus also be transmitted from the mother to the infant during the birth process. ${ }^{28-30} \mathrm{H}$. parainfluenzae infection in the newborn is a relatively rare event and has never been reported in association with water birth. Given the plausible correlation of these two relatively uncommon events, we are prompted to report this association.

\section{Case History}

A 39-week gestation baby boy was born at home, underwater in a birthing tub to a 34-year-old G4 P3 mother. Limited prenatal information was available as the prenatal care was received

April 15, 2015

accepted after revision

May 19, 2015

published online

July 14,2015
DOI http://dx.doi.org/ $10.1055 / \mathrm{s}-0035-1556068$. ISSN $2157-7005$
Copyright $\odot 2015$ by Thieme Medical Publishers, Inc., 333 Seventh Avenue, New York, NY 10001, USA. Tel: +1(212) 584-4662.

\section{License terms}

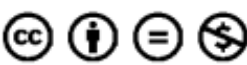


provided predominantly by a midwife and no laboratory tests were done in the final trimester of pregnancy. GBS status was unknown. There was spontaneous rupture of membranes for $>12$ hours before delivery. The duration of labor in the water tub was not documented. The mother reported a rapid vaginal delivery after three pushes. She noted the infant to have a "weak cry" (difficulty getting the infant to cry) at birth, with increased respiratory rate. The Apgar scores at 1 and 5 minutes were 6 and 8 , respectively. A midwife attending delivery documented respirations as "clearing" at the time of the formal physical examination. The day after birth, the parents brought the infant to the emergency room at the local children's hospital because of mild respiratory distress, tachypnea, and poor feeding since birth. The infant was then transferred to the neonatal intensive care unit.

Clinical diagnosis at the time of admission included respiratory distress, suspected sepsis, and pneumonia. Initial chest X-ray revealed a right lower lobe infiltrate, compatible with pneumonia. The patient was placed on $100 \%$ oxygen via nasal cannula and then placed on nasal continuous positive airway pressure (CPAP). Intravenous fluids were started and blood cultures drawn. Initial complete blood count showed white blood cell count of 20,000 with significantly higher numbers of immature neutrophils. C-reactive protein was abnormally high at $11.1 \mathrm{mg} / \mathrm{dL}$. The cerebrospinal fluid showed normal cell counts, glucose, and proteins. Cerebrospinal fluid culture did not grow any organisms.

Respiratory distress was treated by CPAP for the first day. Subsequently, he was weaned to room air for the remaining of his hospital stay. He was initially started on ampicillin, gentamicin, and acyclovir. The antibiotics were changed to ampicillin, ceftazidime, metronidazole, and tobramycin on the 4th day when the blood cultures grew Gram-negative organisms. Later, when the organism was identified as $H$. parainfluenzae that was $\beta$ lactamase negative, all other antibiotics except ampicillin were discontinued and intravenous ampicillin was given for a total of 10 days. An echocardiogram was performed on the 5th day of admission and showed no evidence of endocarditis. The patient's condition improved and was discharged home with his parents on the 12th postnatal day.

\section{Discussion}

The practice of water immersion during labor and birth has grown in popularity in industrialized countries since the 1980s. ${ }^{4,13,31}$ However, most of the research related to infant outcomes from water birth is observational and descriptive, and reported outcomes do not demonstrate causal associations. $^{32}$ Reports have largely shown a positive effect for mothers with no major adverse effects on the infants but concerns regarding associated infection risks have not been allayed. There have been clinical guidelines on water births published by ACOG and AAP that have helped standardize the process. $^{1,2,33}$

Neonatal sepsis because of Haemophilus influenzae is well documented and has recently been increasing, ${ }^{34}$ but Haemophilus species other than $H$. influenzae have been reported to rarely cause human disease. $H$. parainfluenzae, H. aphrophilus, $H$. paraphrophilus, $H$. aegyptius, and $H$. ducreyi are among the species implicated. ${ }^{25}$ Neonatal sepsis associated with $H$. parainfluenzae is extremely rare and the reported cases are shown in -Table 1.

Serious infections because of $H$. parainfluenzae out of the neonatal period have been rarely seen with the first case reported in $1966 .{ }^{35} \mathrm{H}$. parainfluenzae in adults has been shown to cause endocarditis, pharyngitis, otitis media, meningitis, brain abscesses, epiglottitis, pneumonia, conjunctivitis, dental abscess, empyema, septicemia, septic arthritis, osteomyelitis, peritonitis, hepatobiliary infections, epidural abscesses, and urinary tract and genital infections. ${ }^{36-40}$ However, reported pediatric infections have been limited to the upper and lower respiratory tract infections, endocarditis, meningitis, and brain abscesses in infants with long standing respiratory infections. ${ }^{37,39}$ Documented cases of neonatal H. parainfluenzae are still very rare and the 11 reported cases (including ours) are shown in - Table 1. ${ }^{41,42}$ Hable et al suggested that neonatal infections may be rare because of presence of protective maternal antibodies. ${ }^{43}$ An important aspect of $H$. parainfluenzae infection is that $\beta$ lactamase production occurs with a frequency that may be greater than $H$. influenzae; thus, antimicrobial sensitivity is important in determining appropriate antibody treatment. ${ }^{44}$

It has been found that the rates of maternal colonization with $H$. parainfluenzae are low. The reported rate of vaginal carriage during pregnancy is $<1 \%{ }^{45}$ Kinney et al concluded from their study that just $0.3 \%$ of mothers had positive cultures for this bacterium in their genital tract. ${ }^{46}$ On the basis of this information, blood borne vertical transmission of the infection from mother to infant is highly unlikely to have caused the infection in our patient although this possibility cannot be ruled out.

In our reported case, underwater birth of the infant, along with the extremely low rate of maternal blood stream transmission of $H$. parainfluenzae raises the possibility that this organism may have been present in the aqueous environment around the baby during the birth process. The aqueous environment may be seeded secondary to maternal genital tract secretions or primarily as contaminants of the birthing tub or the water used. It is well known that in water births, during the bearing-down phase, gastrointestinal organisms such as E. coli and Staphylococcus aureus contaminate the water environment and Haemophilus species in feces may have been a potential source of the organism. ${ }^{47}$ It is of interest that in a study by Palmer, who inoculated feces on a selective medium, Haemophilus species were isolated from $28 \%$ of 612 samples from patients of all ages; most isolates being H. parainfluenzae. ${ }^{48}$

Despite a growing body of evidence for water birth safety, a myriad of political and cultural issues result in its limited use in the hospitals in United States compared with other developed nations. ${ }^{49}$ It is well recognized that the water used in the water birth can be a major source of infection. Thoeni et al, analyzed 250 water samples taken from the birth pool and installed a special bacteria filter in $2002 .{ }^{6}$ Two water samples were obtained at every water birth, samples were cultured for 
Table 1 Review of literature: newborn infants with Haemophilus parainfluenzae sepsis.

\begin{tabular}{|c|c|c|c|c|c|}
\hline Case & Maternal data & Mode f delivery & Neonatal data & H. parainfluenzae & Outcome \\
\hline $1^{34}$ & $\begin{array}{l}33 \text { y old, ROM } \\
\text { for } 8 \text { days }\end{array}$ & CS at 27 wk GA & $\begin{array}{l}\text { Sepsis, neutrope- } \\
\text { nia, RD, mild DIC, } \\
\text { pulmonary } \\
\text { hypertension }\end{array}$ & $\begin{array}{l}\text { In infant blood and tra- } \\
\text { cheal aspirate }\end{array}$ & Survived \\
\hline $2^{22}$ & $\begin{array}{l}18 \text { y old } \\
\text { PPROM for } 48 \mathrm{~h} \\
\text { Abdominal } \\
\text { tenderness }\end{array}$ & NVD after 29 wk GA & $\begin{array}{l}1.15 \mathrm{~kg} \text { boy, atonic } \\
\text { and dusky, no } \\
\text { spontaneous respi- } \\
\text { rations, Apgar } 2 \text { and } \\
2 \text { after } 1 \text { and } 5 \text { min, } \\
\text { chest X-ray-pneu- } \\
\text { monia, interstitial } \\
\text { opacifications }\end{array}$ & $\begin{array}{l}\text { In placental swabs, } \\
\text { Placenta with chorioam- } \\
\text { nionitis, funisitis }\end{array}$ & Died on 15th PND \\
\hline $3^{35}$ & $\begin{array}{l}20 \text { y old } \\
\text { G2A1 }\end{array}$ & $\begin{array}{l}\text { Baby in breach } \\
\text { CS at } 32 \text { wk GA }\end{array}$ & $\begin{array}{l}1.58 \text { kg, leukope- } \\
\text { nia, weak cry, TCP, } \\
\text { severe RD, IVH } \\
\text { grade III, intubated, } \\
\text { PDA, chest X-ray- } \\
\text { low volume lungs, } \\
\text { hypocalcemia, left- } \\
\text { sided pneumotho- } \\
\text { rax. hyponatremia }\end{array}$ & In infant's blood sample & Survived \\
\hline $4^{44}$ & Amnionitis & $\begin{array}{l}\text { Term gestation } \\
\text { MOD not specified }\end{array}$ & NS & $\begin{array}{l}\text { In infant's CSF and throat } \\
\text { culture. }\end{array}$ & Survived \\
\hline $5^{44}$ & Fever & MOD not specified & $3.46 \mathrm{~kg}$ & In infant's blood & Survived \\
\hline $6^{44}$ & ROM for $20 \mathrm{~h}$ & $\begin{array}{l}\text { Term gestation } \\
\text { NS }\end{array}$ & $2.84 \mathrm{~kg}$ & In infant's blood & Survived \\
\hline $7^{44}$ & ROM for $8 \mathrm{~h}$ & Term gestation & $\begin{array}{l}3.40 \mathrm{~kg} \\
\text { Chest X-ray-left } \\
\text { lower lobe infiltrate }\end{array}$ & $\begin{array}{l}\text { In maternal blood, in- } \\
\text { fant's blood, scalp }\end{array}$ & Survived \\
\hline 8.44 & $\begin{array}{l}\text { Amnionitis } \\
\text { ROM for } 48 \mathrm{~h}\end{array}$ & NS & $\begin{array}{l}0.73 \mathrm{~kg} \\
\text { Pneumonia, HMD }\end{array}$ & $\begin{array}{l}\text { In maternal placenta, } \\
\text { cervix culture and infant's } \\
\text { blood }\end{array}$ & Died \\
\hline $9^{44}$ & $\begin{array}{l}\text { ROM for } 48 \mathrm{~h} \\
\text { Funisitis and } \\
\text { chorioamnionitis }\end{array}$ & NS & $\begin{array}{l}1.15 \mathrm{~kg} \\
\text { Pneumonia, HMD }\end{array}$ & $\begin{array}{l}\text { Growth in maternal pla- } \\
\text { centa culture and infant's } \\
\text { blood. }\end{array}$ & Died \\
\hline $10^{44}$ & NS & $\begin{array}{l}30 \text { wk GA } \\
\text { MOD NS }\end{array}$ & $1.76 \mathrm{~kg}$ & In infant's gastric aspirate & Died \\
\hline Current case & 34 y G4P3 & $\begin{array}{l}39 \text { wk GA } \\
\text { NVD (water birth) }\end{array}$ & $\begin{array}{l}\text { Weak cry } \\
\text { Tachypnea, RD, } \\
\text { poor feeding } \\
\text { Chest X-ray-pneu- } \\
\text { monia (right LL } \\
\text { Infiltrate) }\end{array}$ & In infant's blood culture & Survived \\
\hline
\end{tabular}

Abbreviations: CS, cesarean section; CSF, cerebrospinal fluid; DIC, disseminated intravascular coagulation; HMD, hyaline membrane disease; IVH, intraventricular hemorrhage; LL, left lower; MOD, mode of delivery; NS, not specified; NVD, normal vaginal delivery; PDA, patent ductus arteriosus; PND, postnatal day; PROM, premature rupture of membranes; RD, respiratory distress; ROM, rupture of membranes; TCP, thrombocytopenia; wk GA, weeks of gestation.

Pseudomonas aeruginosa, Escherichia coli, Enterococcus species, Coliforms, and Legionella pneumonia. They also compared the rates of perinatal infection in infants delivered in water with those delivered in air. Overall, $12 \%$ of one sample contained Legionella pneumophila, 11\% Pseudomonas aeruginosa, 19\% Enterococcus species, 21\% Coliforms, and 10\% Escherichia coli. This suggests the importance of disinfecting water before and after use in a water bath as a possible way of limiting infectious complications. In our case, we were unable to obtain bacterial sample from the water in the tub used during delivery.

Training and safety of health personnel involved in water births is another matter of concern. A study of 53 Clinical Nurse Midwives in Georgia by Meyer et al revealed that only $30 \%$ of these professionals had received instruction about water birth in their midwifery training program. ${ }^{50}$ It was shown that midwives' support for water birth was based mostly on the expected benefits to the mother with very little 
attention given to the potential risks to the infant. Another aspect not given adequate attention is the increased risk of exposure to HIV and HBV of health workers involved in water births. ${ }^{51}$ Hence, education of personnel involved in water births on infection safety of the health professional, mother, and infant is of vital importance.

Our current case report along with previous reported cases of neonatal pneumonia and sepsis from other organisms associated with water births suggests that there may be a need to be more vigilant regarding the management, training, and education of midwives (and other practitioners) with a particular focus on infection control during water births.

\section{Financial Disclosures}

None.

\section{Conflict of Interest}

None.

\section{References}

1 Liu Y, Liu Y, Huang X, et al. A comparison of maternal and neonatal outcomes between water immersion during labor and conventional labor and delivery. BMC Pregnancy Childbirth 2014; $14: 160$

2 Mollamahmutoğlu L, Moraloğlu O, Ozyer S, et al. The effects of immersion in water on labor, birth and newborn and comparison with epidural analgesia and conventional vaginal delivery. J Turk Ger Gynecol Assoc 2012;13(1):45-49

3 American Academy of Pediatrics Committee on Fetus and Newborn; American College of Obstetricians and Gynecologists Committee on Obstetric Practice. Immersion in water during labor and delivery. Pediatrics 2014;133(4):758-761

4 Cluett ER, Burns E. Immersion in water in labour and birth. Cochrane Database Syst Rev 2009;(2):CD000111

5 Demirel G, Moraloglu O, Celik IH, et al. The effects of water birth on neonatal outcomes: a five-year result of a referral tertiary centre. Eur Rev Med Pharmacol Sci 2013;17(10):1395-1398

6 Thoeni A, Zech N, Moroder L, Ploner F. Review of 1600 water births. Does water birth increase the risk of neonatal infection? J Matern Fetal Neonatal Med 2005;17(5):357-361

7 Fehervary P, Lauinger-Lörsch E, Hof H, Melchert F, Bauer L, Zieger W. Water birth: microbiological colonisation of the newborn, neonatal and maternal infection rate in comparison to conventional bed deliveries. Arch Gynecol Obstet 2004;270(1):6-9

8 Pinette MG, Wax J, Wilson E. The risks of underwater birth. Am J Obstet Gynecol 2004;190(5):1211-1215

9 Davies MW. Water births and the research required to assess the benefits versus the harms. J Paediatr Child Health 2012;48(9): 726-729

10 Osterman MJ, Martin JA, Mathews TJ, Hamilton BE. Expanded data from the new birth certificate, 2008. National vital statistics reports: from the Centers for Disease Control and Prevention, National Center for Health Statistics. National Vital Statistics System 2011;59:1-28

11 Johnson P. Birth under water-to breathe or not to breathe. $\mathrm{Br} \mathrm{J}$ Obstet Gynaecol 1996;103(3):202-208

12 Thach BT. Maturation of cough and other reflexes that protect the fetal and neonatal airway. Pulm Pharmacol Ther 2007;20(4): 365-370

13 Rawal J, Shah A, Stirk F, Mehtar S. Water birth and infection in babies. BMJ 1994;309(6953):511
14 Thöni A, Mussner K, Ploner F. Water birthing: retrospective review of 2625 water births. Contamination of birth pool water and risk of microbial cross-infection [in Italian]. Minerva Ginecol 2010;62(3): 203-211

15 Elyse F, Kay S, Heidi T, Diana C. Fatal Legionellosis after Water Birth, Texas, USA, 2014. Emerg Infect Dis J 2015;21(1):130-132

16 Franzin L, Cabodi D, Scolfaro C, Gioannini P. Microbiological investigations on a nosocomial case of Legionella pneumophila pneumonia associated with water birth and review of neonatal cases. Infez Med 2004;12(1):69-75

17 Nagai T, Sobajima H, Iwasa M, et al. Neonatal sudden death due to Legionella pneumonia associated with water birth in a domestic spa bath. J Clin Microbiol 2003;41(5):2227-2229

18 Phin N, Cresswell T, Parry-Ford F; Incident Control Team. Case of Legionnaires disease in a neonate following a home birth in a heated birthing pool, England, June 2014. Euro Surveill 2014; 19(29):19

19 Zanetti-Dällenbach R, Lapaire O, Maertens A, Frei R, Holzgreve W, Hösli I. Water birth: is the water an additional reservoir for group $B$ streptococcus? Arch Gynecol Obstet 2006;273(4):236-238

20 Plumb J, Holwell D, Burton R, Steer P. Water birth for women with GBS: a pipe dream? Pract Midwife 2007;10(4):25-28

21 Soileau SL, Schneider E, Erdman DD, Lu X, Ryan WD, McAdams RM. Case report: severe disseminated adenovirus infection in a neonate following water birth delivery. J Med Virol 2013;85(4): 667-669

22 Arias JW, Saldana LR, Conklin R. Chorioamnionitis due to Haemophilus parainfluenzae. Tex Med 1981;77(7):47-48

23 Govind B, Veeraraghavan B, Anandan S, Thomas N. Haemophilus parainfluenzae: report of an unusual cause of neonatal sepsis and a literature review. J Infect Dev Ctries 2012;6(10):748-750

24 Rele M, Giles M, Daley AJ. Invasive Haemophilus parainfluenzae maternal-infant infections: an Australasian perspective and case report. Aust N Z J Obstet Gynaecol 2006;46(3):258-260

25 Chen RV, Bradley JS. Haemophilus parainfluenzae sepsis in a very low birth weight premature infant: a case report and review of the literature. J Perinatol 1999;19(4):315-317

26 García E, Andreu A, Bartolomé RM. Maternal-fetal vertical transmission of Haemophilus influenzae and Haemophilus parainfluenzae [in Spanish]. Enferm Infecc Microbiol Clin 1997;15(2):65-69

27 Hunkert F, Handrick W, Spencker FB, Hückel D. [Neonatal infections caused by Haemophilus influenzae and Haemophilus parainfluenzae]. Zentralbl Gynakol 1988;110(13):816-820

28 Tashjian JH, Coulam CB, Washington JA II. Vaginal flora in asymptomatic women. Mayo Clin Proc 1976;51(9):557-561

29 Quentin R, Musser JM, Mellouet M, Sizaret PY, Selander RK, Goudeau A. Typing of urogenital, maternal, and neonatal isolates of Haemophilus influenzae and Haemophilus parainfluenzae in correlation with clinical source of isolation and evidence for a genital specificity of $\mathrm{H}$. influenzae biotype IV. J Clin Microbiol 1989;27(10):2286-2294

30 Harper JJ, Tilse MH. Biotypes of Haemophilus influenzae that are associated with noninvasive infections. J Clin Microbiol 1991; 29(11):2539-2542

31 Odent M. Birth under water. Lancet 1983;2(8365-66):1476-1477

32 Hershckowitz S, Elisha MB, Fleisher-Sheffer V, Barak M, Kudinsky $\mathrm{R}$, Weintraub Z. A cluster of early neonatal sepsis and pneumonia caused by nontypable Haemophilus influenzae. Pediatr Infect Dis J 2004;23(11):1061-1062

33 Committee on Obstetric Practice; American Academy of Pediatrics. ACOG Committee Opinion no. 594: Immersion in water during labor and delivery. Obstet Gynecol 2014;123(4):912-915

34 Vergnano S, Menson E, Kennea N, et al. Neonatal infections in England: the NeonIN surveillance network. Arch Dis Child Fetal Neonatal Ed 2011;96(1):F9-F14

35 Gullekson EH, Dumoff M. Haemophilus parainfluenzae meningitis in a newborn. JAMA 1966;198(11):1221 
36 Chunn CJ, Jones SR, McCutchan JA, Young EJ, Gilbert DN. Haemophilus parainfluenzae infective endocarditis. Medicine (Baltimore) 1977;56(2):99-113

37 Bachman DS. Hemophilus meningitis: comparison of $\mathrm{H}$. influenzae and H. parainfluenzae. Pediatrics 1975;55(4):526-530

38 Oill PA, Chow AW, Guze LB. Adult bacteremic Haemophilus parainfluenzae infections. Seven reports of cases and a review of the literature. Arch Intern Med 1979;139(9):985-988

39 Black CT, Kupferschmid JP, West KW, Grosfeld JL. Haemophilus parainfluenzae infections in children, with the report of a unique case. Rev Infect Dis 1988;10(2):342-346

40 O'Bryan TA, Whitener CJ, Katzman M, Appelbaum PC. Hepatobiliary infections caused by Haemophilus species. Clin Infect Dis 1992;15(4):716-719

41 Nakamura KT, Beal DW, Koontz FP, Bell EF. Fulminant neonatal septicemia due to Hemophilus parainfluenzae. Am J Clin Pathol 1984;81(3):388-389

42 Zinner SH, McCormack WM, Lee YH, Zuckerstatter MH, Daly AK. Puerperal bacteremia and neonatal sepsis due to Hemophilus parainfluenzae: report of a case with antibody titers. Pediatrics 1972;49(4):612-614

43 Hable KA, Logan GB, Washington JA II. Three Hemophilus species. Pathogenic activity. Am J Dis Child 1971;121(1):35-37
44 Scheifele DW, Fussell SJ. Frequency of ampicillin-resistant Haemophilus parainfluenzae in children. J Infect Dis 1981;143(3): 495-498

45 Wallace RJ Jr, Baker CJ, Quinones FJ, Hollis DG, Weaver RE, Wiss K. Nontypable Haemophilus influenzae (biotype 4) as a neonatal, maternal, and genital pathogen. Rev Infect Dis 1983;5(1): $123-136$

46 Kinney JS, Johnson K, Papasian C, Hall RT, Kurth CG, Jackson MA Early onset Haemophilus influenzae sepsis in the newborn infant. Pediatr Infect Dis J 1993;12(9):739-743

47 Thoni A, Zech N, Moroder L, Ploner F. Water contamination and infection rate after water births [in German]. Gynakol Geburtshilfliche Rundsch 2007;47(1):33-38

48 Palmer GG. Haemophili in faeces. J Med Microbiol 1981;14(1): 147-150

49 Nutter E, Meyer S, Shaw-Battista J, Marowitz A. Waterbirth: an integrative analysis of peer-reviewed literature. J Midwifery Womens Health 2014;59(3):286-319

50 Meyer SL, Weible CM, Woeber K. Perceptions and practice of waterbirth: a survey of Georgia midwives. J Midwifery Womens Health 2010;55(1):55-59

51 Colombo C, Pei P, Jost J. [Water births and the exposure to HIV]. Pflege 2000;13(3):152-159 